\title{
Slovenská a talianska industrializovaná literatúra - medzi ideológiou a literatúrou
}

\author{
Ivan Šuša - Patrizia Prando (Banská Bystrica)
}

\begin{abstract}
Abstrakt
Nasledujúca štúdia sa zameriava na analogické a diferentné aspekty talianskej a slovenskej industriálnej, resp. industrializovanej literatúry. Príspevok prepája literárne a mimoliterárne faktory, najmä vztáah literatúra a politika (ideológia). Autori štúdie - vzhl'adom na ich vedecké zameranie - vychádzajú z ich doterajších výskumov, ako aj z poznatkov d’alších talianskych a slovenských vedcov, hlavne literárnych historikov (Francesco De Nicola, Guido Baldi, Giulio Ferroni, Silvia Giussová, Vilam Marčok, Pavol Koprda a i.). Autori industrializovanú literatúru zarad'ujú aj do širšieho literárno-historického kontextu v oboch krajinách, pričom zdôrazňujú aj spoločensko-politickú objednávku na tento druh literatúry. Špeciálnu pozornost' venujú slovenskému prijímaciemu prostrediu, do ktorého sa diela talianskej industriálnej literatúry (napr. Ottiero Ottieri) dostali prostredníctvom prekladov.
\end{abstract}

\section{Kl'účové slová}

slovenská a talianska industrializovaná literatúra; ideológia; preklad; recepčný kontext

\section{Abstract \\ Slovak and Italian Industrial Literature - between Ideology and Literature}

The following study is focused on the analogical and different aspects of Italian and Slovak Industrial Literature. It connects Literature with other scientific areas - it's possibile to see mainly relations between literatue and politics (especially with ideology). The authors of this contribution (according to their actual researches) bring a results of their studies and also researches of Italian and Slovak literary historians (for example Francesco De Nicola, Giulio Ferroni, Guido Baldi, Silvia Giusso, Vilam Marčok, Pavol Koprda etc). The authors of this contribution integrate the Industrial Literature into the wider literary-history context in both countries and underline also social-political imputs on this kind of Literature. They give a special attention to the context of Slovak receiving ambient through the translation (for example, Ottiero Ottieri) from Italian to Slovak language.

\section{Key words}

Slovak and Italian industrial literature; ideology; translation; receiving context 


\section{Úvod}

V slovenskej i talianskej literatúre sa v povojnovom období zjavila tzv. industrializovaná, resp. industriálna literatúra ${ }^{1}$ - v oboch krajinách i spoločensko-kultúrnych prostrediach a v ohraničenom časovom období v podstate splnila svoj účel i funkciu. Pôvodná (a na prvý pohlad nie zlá) myšlienka podpory spriemyselňovania, technického rozvoja a civilizačného rozmachu aj prostredníctvom krásnej literatúry (poézie i prózy), satiry a publicistiky však so sebou priniesla aj negatívne javy. V slovenskom kontexte skĺzla do schematizovanej podoby a oslavného pátosu éry industrializmu, v talianskom kontexte propagovala kapitalizmus a kapitál konkrétnych podnikov, firiem a spoločností. Neskôr (stále v prípade Talianska) sa stala kritickým hlasom proti zneužívaniu l’udskej práce, nahrádzaniu l’udského potenciálu strojmi a ukážkou sociálnej nerovnosti na osi zamestnávatelia-zamestnanci, ale aj regionálnych disproporcií v rámci Apeninského polostrova (už vtedy boli viditel’né výrazné sociálne rozpory krajiny, pomyselne rozdeleného na sever a juh). Navyše, slovenskú industrializovanú literatúru musíme vnímat’ aj v kontexte budovania priemyslu na Slovensku, a teda ako ekonomické a hospodárske „vyrovnávanie“ sa s českou častou spoločného štátu.

Taliansky literárny teoretik Francesco De Nicola, pôsobiaci na janovskej univerzite, uvažuje v širšom kontexte (s areálovými presahmi) o triáde literatúra - priemysel - kultúra ako o „literatúre rokov obnovy a kultúrneho priemyslu”", literárni historici a kritici Cesare Segre a Clelia Martignoniová hovoria o „kultúrnom priemysle”. ${ }^{3}$ Guido Baldi a Silvia Giussová ju priamo terminologicky (ako extenziu pojmu) a ani genologicky bližšie nešpecifikujú, tiež však zdôrazňujú vztah priemysel - literatúra a vztah „literatúra a svet priemyslu”. "Giulio Ferroni zasa hovorí o „spisovatel'och v obdobi rozvoja Talianska”, ${ }^{5}$ teda jednotlivých autorov industriálnej literatúry časovo usúvztažňuje a zasadzuje do kontextu tamojšej literárnej histórie. Vittorio Sereni v tejto súvislosti vyzdvihuje potrebu odklonit sa - tematicky i výrazovo - od hermetizmu a neorealizmu a nastúpit novú cestu literatúry, ktorá však nebude mat ako svoj objekt (tému) len priemysel, ale prítomnost̉ priemyslu by mala byt determinantom v každodennom živote.

Slovenská industrializovaná literatúra zasa našla konkretizáciu vo výrobnom románe. Náš [vo význame slovenský - pozn. I. Š.] výrobný román však nebol úplným objavom, len reportážnou aktualizáciou profesijných románov naturalizmu, napr. o trhovníkoch, rybá-

1 Pojmy „industrializovaná“ a „industriálna“ považujeme v našom príspevku za terminologicky rovnocenné, vychádzajúce z rovnakej sémantickej motivácie. V slovenskom literárnovednom kontexte sa viac používa pojem „industrializovaná literatúra“, v talianskom kontexte „industriálna literatúra“ (la letteratura industriale).

2 DE NICOLA, Francesco: Letteratura italiana contemporanea. Dall' Unità nazionale all'era televisiva. Genova: De Ferrari, 2006, s. 103.

3 SEGRE, Cesare - MARTIGNONI, Clelia: Testi nella storia. La letteratura italiana dalle origini al Novecento. Il Novecento. Volume 4. Pioltello (Milano): Mondadori, 1992, s. 1378.

4 BALDI, Guido - GIUSSO, Silvia: La letteratura. Dal dopoguerra ai giorni nostri. Pioltello (Milano): Paravia, 2007, s. 210.

5 FERRONI, Giulio: Storia della letteratura italiana. Il Novecento e il nuovo millenio. Milano: Mondadori, 2013, s. 446. 
roch, makléroch atd'. Na zobrazovanie dejovo nevýrazných pracovných hrdinstiev „úderníkov" sa najčastejšie využívali dokumentárno-publicistické žánre, ako sú črta či reportáž, príp. dráma. ${ }^{6} \mathrm{~V}$ súčasnosti viacerí slovenskí literárni historici vnímajú výrobný román a v širšom kontexte schematizovanú industrializovanú literatúru v rámci slovenských dejín literatúry skôr ako vynútené intermezzo a nevenujú mu výraznejšiu pozornost’ (vari s výnimkou spomínaných - Reného Bílika, Viliama Marčoka či čiastočne Imricha Sedláka). Táto problematika sa prakticky vytratila aj zo slovenských čítaniek a učebníc literatúry (na rozdiel od talianskych, ktoré síce len parciálne, no objektívne a v rámci areálových vztahov $^{7}$ zasadzujú tento typ literatúry do talianskeho literárnohistorického kontextu). Ako jeden z nosných ponovembrových počinov považujeme vydanie publikácie Čítame slovenskú literatúru I.-III., ktorá ponúka nielen vybrané texty z oblasti prózy daného obdobia (z hladiska žánrovej formy máme na mysli výrobný román) a poézie (občiansko-politická poézia), ale ich aj komentuje a časovo-kauzálne usúvzṫažňuje.

\section{Slovenská industrializovaná literatúra v kontexte spoločensko- kultúrneho a politického prostredia}

V súčasnosti môžeme jednoznačne konštatovat, že slovenská industrializovaná literatúra predstavuje v dejinách slovenskej literatúry angažovaný, ideologicky poddajný model literatúry, ktorého úlohou bolo propagovat budovatel’skú politiku štátu a strany, oslavovat nadšenie pracujúcich z výdobytkov techniky a industrializácie krajiny (realistická budovatel'ská literatúra). Je logické, že z literárnohistorického hladiska zohrala len parciálnu úlohu, temporálne obmedzenú najmä na obdobie pätdesiatych a čiastočne šestdesiatych rokov 20. storočia. Tento typ literatúry u nás reprezentoval „absenciu spontaneity a prirodzeného, zvnútra literárneho organizmu vychádzajúceho pulzovania literárneho života, literárny život v prvej polovici pät’desiatych rokov nefungoval, nepulzoval, ale bol vytvárany“. ${ }^{8}$ Ostrá kritika sa vtedy vznášala najmä proti davistickej a nadrealistickej avantgarde, jednotliví spisovatelia sa zaväzovali štátu a strane ku konkrétnym umeleckým výkonom (napísanie novej básnickej zbierky či románu v zhode s naznačenou doktrínou a metódou).

Politicky angažovaní autori sa podriad’ovali vytýčeným úlohám (spomeňme Širokého Súborný plán Slovenska) a potrebám a témam zo záverov profesijných spisovatelských a straníckych zjazdov. Naopak, kritike boli vystavené diela, ktoré realisticky zobrazovali stav súdobej spoločnosti a jej sociálny status (napríklad Tatarkov román Proý a druhý úder), Lajčiakove úvahy sa zhmotnili do úvodného referátu už na zasadnutí slovenskej sekcie Zväzu československých spisovatelov a na stránkach Kultúrneho života, napr. v článku Somknút sily na pomoc súbornému plánu ${ }^{9}$ : vytvorit atmosféru práce a radostného

6 MARČOK, Viliam a kolektív: Dejiny slovenskej literatúry III. (Druhé, rozšírené vydanie). Bratislava: Literárne informačné centrum, 2006, s. 181.

7 Porov. POSPÍŠIL, Ivo: Literárni věda a teritorialni studie. Nitra: FSŠ UKF, 2013.

8 BÍLIK, René: Duch na retazi. Sondy do literárneho života na Slovensku v rokoch 1945-1989. Bratislava: Kalligram, 2008, s. 47.

9 Tamže, s. 53. 
úsilia, porovnat plány a záväzky s úlohami súborného plánu a určit program krúžku básnikov a prozaikov, zúčastňovat sa na verejnom živote v celej šŕrke, urýchlit vydávanie klasikov či postarat’ sa o skutočnú výchovu začínajúcich spisovatelov.

Postupne sa ukázalo, že „literatúra začína pocitovat potrebu zbavit’ sa neproduktívnej fascinácie industrializmom, sociálnym inžinierstvom či urbanizmom "10 a najmä po druhom zjazde československých spisovatelov (po roku 1956) „radikálnym spôsobom demaskovali odludštenú podobu industrializovanej literatúry a inžiniera ludských duši a otvorili perspektívu pre individuálny, osobnostne dotovaný tvorivý výkon i pre priestor na jeho realizáciu“."

Najmä v prvej polovici pätdesiatych rokov sa začína v slovenskej literatúre programovo prepájat téma Slovenského národného povstania (vítazstvo slovenského ludu nad fašizmom, pomoc Sovietov pri oslobodzovaní) s témou budovania socializmu, ako to vidíme na príklade Tatarkovho „románu epochy“ Proý a druhý úder (1950). V literatúre sa tiež búral stereotyp dovtedy chudobnej slovenskej dediny - to prostredníctvom idey socializácie (v užšom slova zmysle máme na mysli zakladanie jednotných rol’níckych družstiev, no celkovo aj boj s kulakmi a vlastníkmi pôdy či statkov). Individuálne vlastníctvo spojené s kapitalizmom sa myšlienkovo vymedzovalo ako hlavný protipól k myšlienke spoločného či kolektívneho, t. j. k atribútom socializmu. Svedčí o tom Hečkova Drevená dedina (1951), Lazarovej Osie hniezdo (1953), Gabajovi Ryžiari (1953), Tatarkov Radostnik (1954) či Družné letá (1955). Od autorov sa očakával heroizmus, optimizmus, viera v svetlé zajtrajšky, spojená s rozvojom socialistickej spoločnosti, priemyslu a pol’nohospodárstva. Za prvý schematický budovatelský či výrobný román môžeme považovat vy̌šie spomenutý Tatarkov Pruý a druhý úder. Paradoxne, ani ten sa vo vtedajšej slovenskej literárnej kritike nestal exemplárnym príkladom „správneho“ budovania socializmu - práve naopak, niektorí kritici (za všetkých spomeňme napríklad Roznera) dielo zhodnotili ako málo socialistické či málo robotnícke. Špecifickým prípadom je Alfonz Bednár (narážame najmä na jeho román Sklený vrch z roku 1954), ktorý sa oproti preferovanej próze onoho obdobia bližšie posúva bližšie k človečenstvu, z literárnovedného hladiska tenduje k zdôrazňovaniu vnútorného sveta postáv, $\mathrm{k}$ opisu prežívania postavy a celkového uvažovania o svete z pozície intelektu (napríklad Števček si v jeho prípade všimol spojenie výrobného románu s intelektuálnym).

Túžba po rýchlom zbohatnutí či pranierovanie nedostatkov v polnohospodárstve sa viaže na bohatú tvorbu Kataríny Lazarovej, romány zo stavbárskeho prostredia zasa prezentoval širokému slovenskému čitatelstvu Peter Ševčovič (Mesto plné chlapov, 1963 a o dva roky neskôr Čakaj nás, Angela), spomeňme aj Petra Severa (Malá slávobrána, 1961), Horákove Šachty (1953), Vysoká pec (1950) a Na baňu klopajú (1954) oslavovali prácu baníkov a baníckeho stavu a v celkovom kontexte nemožno obíst ani Mináčov román Výrobca štastia (1966) či dvojnovelu Nikdy nie si sama (1962) s jasnou budovatel'skou a optimistickou ideou.

Spojenie literárnych a mimoliterárnych (spoločensko-ekonomických) faktorov sa ukázalo aj v charaktere slovenskej literatúry vo vztahu k naznačenej téme. Kým v prvej po-

10 Tamže.

11 Tamže, s. 56. 
lovici pätdesiatych rokov sa napríklad riešila téma kolektivizácie, oslavovali sa vybrané profesie (spomínaní baníci, práca na stavbách a podobne), reálna oslava industrializmu a spriemyselňovania krajiny nastala až neskôr (t. j. po zverejnení plánu industrializácie po roku 1955). Ako konštatuje Viliam Marčok, „slovenski prozaici, pochádzajúci vä̈činou $z$ vidieka, mali sklon dávat prednost’ zobrazovaniu fyzického zápasu s prírodou pred riešením organizačných, technologických či výskumných úloh". ${ }^{12}$

Schematické vnímanie skutočnosti s exaltáciou industrializácie a kolektivizácie sa prejavilo nielen $\mathrm{v}$ slovenskej próze, ale aj v poézii, a to najmä v tzv. občiansko-politickej lyrike. Ak nerátame oslavné skladby pri príležitosti sedemdesiatich narodenín Stalina (napríklad Pozdrav z pera Milana Lajčiaka z roku 1949 či Na Stalina od Jána Kostru, taktiež z roku 1949), ktoré teraz nie sú predmetom našich úvah, no dokreslujú celkový spoločensko-politický a kultúrny kontext a postavenie literatúry v spoločnosti, tak stojî za spomenutie napríklad Lajčiakova zbierka Súdružka moja zem z roku 1949. Autor v nej píše o neznámom súdruhovi Jánovi, ktorý pracuje vo fabrike pre seba, stranu a pre spoločnost̉ (,pochopil som, že štastie v rukách mám“, „lepšie a rýchlejšie podkovy vyrábam“). Ďalší autori vo fabrikách a podnikoch vychovávali k poézii, napríklad Ján Kostra v zbierke Javorový list (1953) v básni Po diskusii o poézii v závodnom klube (v hale tažkého strojárenstva).

Celkovo je potrebné poznamenat, že v uvedenom období dochádzalo k výraznej typizácii a simplifikácii postáv (jednoduchý robotník, malorolník, družstevník, učeň, baník), vyššie uvedený neznámy súdruh Ján či Plávkov Ferko Janík z Malužinej.

Vojtech Mihálik v Spievajúcom srdci (1952) pís̃e o „orchestri lešenı", „vrchoch v klieštach strojov stlačených“, o stavaní elektrární, pričom budovanie fabrík a elektrární motivicky usúvztažňuje s budovaním strany a štastného života (,ak stranu staviaš, z tvojej práce vstáva“). V tejto súvislosti tiež nemožno obíst̉ poéziu Ctibora Štítnického, najmä Pochod miliónov z roku 1949 a Jarná pieseň družstevnika (1950), v ktorej oslavuje „spievajúce polia“ či „spev mladej traktoristky“, ktorá žiari ako spln, ked” si sadá za traktor. Autor rovnako ako d’alší spomenutí autori schematizuje postavenie družstevníka a robotníka (,v bublavých bubnoch mocných mlynov, ked' robotnik má silu takú, že hýbe nimi elektrinou“). Schematické básne, ktoré prepájajú oslavu strany, industrializácie a kolektivizácie, predstavuje aj tvorba Milana Ferka, najmä v Zväzáckej cti (1951) či Vítaznej mladosti (1953). Glorifikujúce ódy na spojenie práce a straníckej poslušnosti sú viditelné napríklad v jeho básni Mladá družstevnićka u súdruha Zápotockého práve zo spomínanej Vítaznej mladosti. Do budovatelskej tematiky sa u nás zapojil aj Pavol Gašparovič Hlbina, najmä v zbierkach Ozveny slnka z roku 1950, o dva roky neskôr Mierové ráno a Ruže radosti z roku 1955, a to s netradičným, ba až absurdným spojením náboženských a komunistických ideových postulátov - napríklad, ako sa Pán Boh pozdravil čest práci a podobne. Hlbina sa snažil zobrazit určité pracovné nástroje či prostriedky umelecky, t. j. s použitím metafor (napr. v Mierovom ráne traktor, ktorý zaorie špinu, lakomstvo, závisť či hnev), celkové básnické vyznenie a čitatel'ský zážitok sú však v takomto spojení diskutabilné.

12 MARČOK, Viliam a kolektív: Dejiny slovenskej literatúry III. (Druhé, rozšírené vydanie). Bratislava: Literárne informačné centrum, 2006, s. 174. 


\section{Talianska industriálna literatúra - jej špecifiká a diferencie vo vzt’ahu východisková (talianska) a prijímajúca (slovenská) kultúra}

V dejinách talianskej literatúry zhmotňoval charakteristiky industriálnej literatúry priemyselný román. Ide o obdobie, kedy sa neorealizmus postupne stáva anachronickým javom, potvrdzuje sa nástup neoavantgardy a postmoderny, aj ked' sociálne a etické problémy ostávajú relevantnou tematikou talianskej literatúry aj v neskoršom období. Na konci pätdesiatych a na začiatku šesṫdesiatych rokoch 20. storočia totiž nastáva v Taliansku obrovský ekonomický boom. Aj vd’aka masívnej americkej hospodárskej pomoci, rozvoju tažkého i lahkého priemyslu, stavebníctva, automobilizmu a súkromného sektora sa Taliansko postupne dostáva z tvrdých ekonomických a sociálnych tráum, spôsobených najmä dvoma svetovými vojnami (strata rodinných príslušníkov vo vojne, nezamestnanost', pretrvávajúci problém s poloanalfabetizmom) a d’alšími okolnostami (regionálne disproporcie, technologická zaostalost', rozdelenie krajiny podl’a kl’úča priemyselný sever a pol’nohospodársky juh). Nosným priemyselným a podnikatel’ským lídrom sa okrem Fiatu stáva firma Olivetti. Práve syn jeho zakladatela Camilla - Adriano Olivetti - zohral dôležitú úlohu v budovaní dialógu medzi svetom priemyslu a kultúrou a v užšom vzṫahu i s literatúrou. Jeho ciel’om bolo nájst’ vztah medzi viacerými binaritami, ktoré rozdel'ovali spoločnost', a to najmä protichodné ideové a svetonázorové vztahy na osi socializmus - kapitalizmus. Ako vyplýva z jeho diela Idea konkrétneho spoločenstva (L'idea di una comunità concreta) s podtitulom Za krestáanskú civilizáciu (Per una civiltà cristiana) z roku 1958, „ideálnym cementom v solidarite medzi sociálnymi silami je krestáanstvo”. ${ }^{13}$ Pod vplyvom ideí francúzskych kazatloov Maritaina a Mouniera priemyselník a myslitel’ židovského pôvodu zdôrazňoval najmä pojmy personalizmus a komunitarizmus (odtial' aj pojem spoločenstvo, resp. komunita v jeho prácach). Aj vd’aka nemu vznikol v Taliansku časopis Civilizácia strojov (Civiltà delle macchine), ktorého šéfredaktorom sa stal dizajnér a spisovatel' Leonardo Sinisgalli (1908-1981) a vydavatel'stvo Edizioni di Comunità. Okolo Olivettiho sa združilo viacero relevantných intektuálov, najmä spisovatel’ov a básnikov, ako Ottiero Ottieri (1924-2002), Paolo Volponi (1924-1994) - obaja pracovali priamo v jeho firme a aj samotné Ottieriho romány, najmä Donnarumma v útoku (Donnarumma all'assalto) a Volponiho Memoriál (Memoriale) sú lokalizované do Olivettiho fabriky na výrobu písacích strojov, Franco Fortini (vlastným menom Franco Lattes, 1917-1994), Giovanni Giudici (1924-2011) či literárny kritik Geno Pampaloni (1918-2001). ${ }^{14}$

13 BALDI, Guido - GIUSSO, Silvia: La letteratura. Dal dopoguerra ai giorni nostri. Pioltello (Milano): Paravia, 2007, s. 209.

14 V kontexte talianskej industriálnej literatúry je potrebné spomenút aj aktivity redaktorov a spisovatelov, združených okolo viacerých časopisov - Officina (1955-1959, spojený s menom Pier Paolo Pasolini), Politecnico (1945-1947, spojený s menom Elio Vittorini), no najmä Il Menabò. Posledne menovaný časopis vychádzal v rokoch 1959-1967 v priemyselnom centre - v Turíne, ktorý založil Elio Vittorini a riadil Italo Calvino - dve výrazné osobnosti talianskej povojnovej literatúry a kultúry. Jeho celé štvrté číslo (z roku 1961) je venované vztahu literatúra a priemysel (časopis bol typický tým, že často vychádzal ako monotematický, okrem uvedenej témy to bola napr. aj téma vztahu jazyk - nárečie a podobne). Aj v dalších číslach ( $\mathrm{v}$ roku 1962) sa časopis kontinuálne vracal $\mathrm{k}$ tejto téme a dával priestor aj d'alším nosným spisovatelom a intelektuálom, ako boli napríklad Franco Fortini či Umberto Eco. Časopis postupne získaval kontakty 
Ottiero Ottieri najprv v diele Tordé normy (Tempi stretti), neskôr aj v Denníku psychológa (Donnarumma all'assalto, doslova Donnarumma v útoku, 1959), ktoré bolo preložené aj do slovenčiny (mimochodom, dielo môžeme považovat za jeho najznámejšie), rieši tému zapojenia sa intelektuálov do priemyselného života (čo vyvolalo v Taliansku výraznú spoločenskú diskusiu), potrebu ponúk práce stále chudobnejšiemu juhu krajiny (práve v tomto diele napríklad hovorí o tom, ako Olivetti vytvoril pobočku svojej fabriky v Pozzuoli pri Neapole), no nebráni sa ani realistickému zobrazovaniu každodennej reality v pracovných vztahoch, napr. napäté situácie pri výberových konaniach na jednotlivé miesta. Román má denníkový charakter, autor si všíma názory, pozoruje konanie l’udí z pozície psychológa - aj preto sa do slovenského prostredia dostalo prostredníctvom prekladu Maríny Mihálikovej Hečkovej pod názvom Dennik psychológa (v roku 1980). Pre text sú príznačné krátke a úsečné vety, komentovanie a hodnotenie konania jednotlivých pracovníkov je často vo forme poznámok, úvah: „Mám preskúmat’ jeho prácu [...]. Narodil sa v Santa Marii a žil v Ligúrii. Matka je zo severu. Teraz sa vrátil sem do továrne, pred pol druha rokom. Otravuje sa. Nebojácne predstiera mužnost’ a istotu. - Čakám, kedy na moje miesto dajú ženu. Je to pril'ahká práca. Na severe by to zvládla aj žena. - Na pohl’ad to vyzerá vel’mi jednoducho: ženy však už neprijimame, lebo sme zavaleni mužskou nezamestnanostou." 15

„Takzvaný priemyselný román druhej polovice pät'desiatych rokov nenaplnil Vittoriniho očakávanie. Priemyselné romány týchto autorov však priniesli cenný poznatok, že priemyselné odcudzenie sa dá traktovat' ako jazykové, a teda je vlastnou, sociálne ukotvenou pôdou experimentálnej literatúry. Tento poznatok potom naplno využil Volponi." ${ }^{16}$ „Volponi tému odcudzenia sa manifestuje prostrednictvom neurotických postáv [...] vo svete, v ktorom chýba alternatíny pohlad na deštruktínny a neludský svet". ${ }^{17}$ Volponiho dielo Memoriál (Memoriale, 1962) napríklad zobrazuje pohnuté osudy robotníka Albina Saluggia vo fabrike, v ktorej pracuje. Sukcesívne radenie jednotlivých udalostí dáva tušit, že autor chce hlavnú postavu zobrazit’ v celej naratívnej šírke (od jeho prijatia do fabriky hned' po vojne - v roku 1946, cez pomery v nej až po jeho prepustenie o desat’ rokov neskôr). Dielo má nielen sociálny, ale aj výrazne spoločenský charakter - Albino je totiž prepustený z dôvodu, že podporil štrajk za zlepšenie pomerov vo fabrike. Stáva sa teda obetou systému, ktorý síce priniesol prácu, no nie sociálne práva a istoty. Z d’alších autorových diel uved'me Svet stroj (La machina mondiale, 1965, v češtine vyšlo ako Světa stroj v roku 1968 v interpretácii Zdeněka Digrina) a Korporál (Corporale), v neskoršom období napísal Vojvodskú oponu (Il sipario ducale, 1975, v češtine ako Vévodská opona v preklade Josefa Hajného). Volponi

s tamojšou neoavantgardou, ktorá sa v tom období začala formovat. Vittorini s Calvinom chceli pre svoje myšlienky získat aj širšie medzinárodné čitatel'stvo a preto je siedme číslo „otvorené” aj smerom k Francúzsku a Nemecku, no napokon sa opät uzavrel do talianskeho priestoru. Olivettiho iniciatíva, ako aj aktivity Il Menabò smerovali k rúcaniu bariér medzi dvoma kultúrami - vedecko-technologickou a humanitnou. Autori industriálnej literatúry sa sústred’ovali na aktuálne problémy vtedajšej doby, boli presvedčení o ich ideách a „nehladali okamžitý úspech“ (DE NICOLA, Francesco: Letteratura italiana contemporanea. Dall’ Unità nazionale all'era televisiva. Genova: De Ferrari, 2006, s. 109).

15 OTTIERI, Ottiero: Dennik psychológa. Prel. Marína Miháliková-Hečková. Bratislava: Tatran, 1980 , s. 35.

16 KOPRDA, Pavol: Talianska literatúra (zväzok 8a.) Dvadsiate storočie do fašizmu. Nitra: FF UKF, 2014 , s. 40.

17 SEGRE, Cesare - MARTIGNONI, Clelia: Testi nella storia. La letteratura italiana dalle origini al Novecento. Il Novecento. Volume 4. Pioltello (Milano): Mondadori, 1992, s. 1370. 
bol výrazným propagátorom komunistickej idey, neskôr sa však angažoval ako nezávislý reformátor - stále mal však blízko k myšlienke sociálnosti a kritiky tzv. talianskeho neokapitalizmu (v roku 1983 kandidoval ako nezávislý v radoch PCI - Partito Comunista Italiano a v roku 1991 na kandidátke strany Rifondazione Comunista).

Aj d’alší autori, ktorí priamo neparticipovali na Olivettiho projekte, sa v dielach dotýkali témy industrializácie spoločnosti, ako napríklad Goffredo Parise (1929-1986), Lucio Mastronardi (1930-1979) a Vittorio Sereni (1913-1983). Charakter ich tvorby a štýl nie je oslavný, naopak, vyjadrujú kritický šlah vtedajšej industrializovanej dobe. Napríklad Pariseho názory v románe Šéf (Il padrone, 1965, do češtiny preložené ako Pan šéf - v preklade Josefa Hajného vyšlo o pätnást’ rokov neskôr od vyjdenia originálu), v ktorých si všíma odcudzenie sa človeka ako jedinečného indivídua vo svete priemyslu. V slovenčine ho registrujeme v roku 1967 pod názvom Šéf. Dodajme, že z Pariseho prác máme v slovenčine, resp. v češtine preložené skôr diela, ktoré sa výrazne alebo v niektorých prípadoch vôbec nezaoberajú témou industrializácie, napríklad Pekný kňaz (Il prete bello, 1954) ako Fešák kněz (1977) v preklade Josefa Hajného alebo Mŕtvy chlapec a kométy (Il ragazzo morto e le comete, 1951) ako Chlapec a komety (1978, prel. Eva Zaoralová, v češtine vyšli takmer po sebe). Nerovnomerné sociálne rozpoloženie spoločnosti, brutalita okolitého sveta a egoizmus, sú zasa základom Mastronardiho diel, situovaných do Vigevana, kde pôsobil ako učitel'. Sereni dokonca začal tému traktovat’ v poézii a prácu vníma ako „nel’udské väzenie", ako to môžeme vidiet’ v diele Návšteva vo fabrike (Una visita in fabbrica). Nanni Balestrini (1935) v diele Chceme všetko (Vogliamo tutto) zobrazuje život robotníka, ktorý sa musel prestahovat za prácou z juhu na sever Talianska do turínskej fabriky FIAT-u. Tvorba u nás pomerne neznámeho Oreste Del Buona (1923-2003) je už koncipovaná do širšieho filozofického kontextu ako hladanie dôvodov existenciálnej prehry povojnovej generácie a dezilúzie. Originálna je aj tvorba Luciana Bianciardiho (1922-1971) zo sveta kultúry a editorskej činnosti (v tejto oblasti autor pracoval). V slovenskom preklade vyšli aj knihy od Anny Bantiovej (Zlaté mušky, 1980) v Mikulajovej preklade (mimochodom, presne v roku, kedy vyšiel aj Dennik psychológa) či Soldatiho Herca (Mikuláš Pažítka, 1984).

Talianski literárni vedci Guido Baldi a Silvia Giussová zarad’ujú k predstavitel’om talianskej industriálnej literatúry napríklad aj tvorbu svetoznámeho židovského autora Prima Leviho ${ }^{18}$ s dôvetkom, že zobrazuje "pozitívnu viziu pracovného sveta”, ${ }^{19}$ resp. „nekritickú a originálnu viziu sveta fabriky, pokúšajúc sa zmierit’ vedeckú a humanitnú kultúru”. ${ }^{20} \mathrm{~V}$ tejto súvislosti je však potrebné pripomenút, že aj ked’ sa v Leviho tvorbe objavuje téma pracovného sveta, ide najmä o konkrétne zážitky profesie chemika (aj v dielach memoárovej tvorby, ktorú publikoval po návrate z koncentračného tábora - napríklad zdôrazňuje, že jeho povolanie chemika mu v lágri zachránilo život) a časté sú u neho motívy, ktoré

18 Levimu sa venujeme vo viacerých našich vedeckých prácach, porov. napríklad ŠUŠA, Ivan: Holokaust v talianskej a slovenskej memoárovej literatúre. Brno: Tribun EU a Filozofická fakulta Masarykovej univerzity, 2009. Téme sme sa venovali aj v rámci doktorskej práce pod vedením profesora Iva Pospíšila na FF MU v Brne v programe literárna komparatistika.

19 BALDI, Guido - GIUSSO, Silvia: La letteratura. Dal dopoguerra ai giorni nostri. Pioltello (Milano): Paravia, 2007, s. 210. 
súvisia s prácou (aj nútenou - opät v lágroch, po vojne ako rehabilitácia autora aj vo svojej profesionálnej oblasti chemika). Tvrdíme, že pre dejiny literatúry je Levi nosnou osobnostou vd’aka svojej memoárovej tvorbe a len parciálnou častou ho môžeme zaradit k osobnostiam industrializovanej literatúry. Spomeňme však dielo Periodický systém (Il sistema periodico). Levi v ňom približuje osud študenta chémie, čiastočne sa vracia k obdobiu deportácie (napríklad hovorí o plánovanom stretnutí s doktorom Múllerom, ktorý bol jeho nadriadeným v táborovom laboratóriu, no napokon sa ich stretnutie neuskutoční), cez prácu chemického inžiniera po návrate z koncentračného tábora až po sedemdesiate roky dvadsiateho storočia (teda po vydanie knihy). Kapitoly sú nazvané podla jednotlivých chemických prvkov, v diele sa prelína rozprávanie o svojom živote s pútavým rozprávaním o otázkach chémie, resp. jednotlivých chemických prvkoch.

\section{Talianska industriálna literatúra a slovenský prijímajúci kontext}

Talianska industriálna literatúra nemala $\mathrm{v}$ slovenskom ${ }^{21}$ prekladovom a recepčnom kontexte pred a ani po roku 1989 výrazný ohlas. Aj slovenský talianista Pavol Koprda si všíma, že na jednej strane sme preložili Ginsburgovej román Drahý Michal (Caro Michele) - aj to najprv len do češtiny v sedemdesiatych rokoch 20. storočia -, no „ani len spomenutý nebol Paolo Volponi, ktorý románmi o odsudzeni Memoriál (Memoriale, 1962), Svet stroj (Macchina mondiale, 1965) a Korporál (Corporale, 1974) vytvoril v talianskej literatúre epochu a je nepochybne medziliterárny zjav ako napriklad Calvino“.22

Dôvodov je nepochybne niekolko, na základe našich výskumov sa ich pokúsime zosystematizovat do nasledujúcich záverov. $\mathrm{Z}$ ideologického hladiska bolo pre prijímanie tohto typu literatúry problémom najmä zobrazovanie hospodárskych úspechov (ekonomického boomu) západného sveta, ktorý sa začal formovat po poskytnutí pomoci Taliansku v rámci Marshallovho plánu (pripomeňme jeho odmietnutie v Československu a v krajinách tzv. východného bloku), rozvoj kapitalizmu, súkromného sektora, spolupráca Talianska so západným hospodárskym svetom, ako aj finančná podpora tamojších priemyselných velkopodnikatelov do kultúry a literatúry. Nosná úloha intelektuálov v talianskej spoločnosti (a ich podpora) bola v kontrapozícii so zdôrazňovaním úlohy a podstaty robotníckej triedy v Československu (inteligencia nazývaná „panskými komunistami““23). Vittoriniho meno bolo napríklad spojené s predchádzajúcimi diskusiami o úlohe intelektuálov v spoločnosti (máme na mysli diskusiu medzi Vittorinim a vtedajšou Komunistickou stranou, najmä s Palmirom Togliattim - išlo najmä o článok v časopise Politecnico zo dňa 29. 9. 1945 Una nuova cultura, ktorý rozpútal vzájomnú polemiku). Autor,

21 Aj ked' v príspevku uvažujeme o slovenskom prijímajúcom prostredí, nemožno ho úplne oddelit od českého prekladového kontextu (vzhladom na existenciu spoločného štátu, blízkost jazykového kódu a dostupnoste českých prekladov) a aj preto v práci naznačujeme niektoré preklady industriálnej literatúry $\mathrm{z}$ taliančiny do češtiny.

22 KOPRDA, Pavol: Talianska literatúra v slovenskej kultúre v rokoch 1890-1980. (Stručné dejiny umeleckého prekladu na Slovensku. Zv. 1. Talianska literatúra). Bratislava: Ústav svetovej literatúry SAV, 1994, s. 63.

23 Porovnaj napr. Baštovanského názory v Novom slove z roku 1951, č. 11, s. 202. 
podobne ako niektorí d’alší, bol navyše vel'kým propagátorom angloamerickej literatúry a aj jej prekladatelom² ${ }^{24}$ Nemožno tiež obíst’ svetonázorovú (konzervatívno-krestanskú) orientácia nosnej osobnosti priemyselného sveta (Olivettiho).

Nosným rozdielom však bolo postupné ideologické vzd’al'ovanie sa sveta talianskej a československej politiky a kultúry (rok 1948 - prehraté vol'by komunistov v Taliansku a nástup Krestanskej demokracie - DC, naopak, v Československu nástup Komunistickej strany - KSČ). Krestanská demokracia prakticky opantala taliansku politiku až do devätdesiatych rokov 20. storočia. Ako recepčný problém vnímame aj výrazne uzavreté talianske prostredie a zobrazovanie talianskej aktuálnej situácie (industrializácia Talianska, prekonávanie rurálneho života, vyrovnávanie ekonomicko-sociálnych diferencií na osi sever = juh krajiny), ktorá sa postupne vzd’alovala od každodennej reality v Československu. U nás sa prejavoval špecifický obraz recepčného literárno-kultúrneho prostredia - ako sme uviedli, v Československu sa v pätdesiatych rokoch 20. storočia síce paralelne rozvíjala politicky angažovaná budovatel’ská literatúra, oslavujúca spriemyselňovanie krajiny a kolektivizáciu (čím by mohol vzniknút dojem tematickej a žánrovej analógie), no charakter talianskej industrializovanej literatúry nebol oslavný (teda napr. glorifikujúci úspechy vlády či strany), naopak, často kriticky zobrazoval odcudzenie sa človeka a stratu osobnosti jednotlivca.

Hlavnými postavami talianskej industriálnej literatúry - na rozdiel od slovenskej - sú často antihrdinovia, napríklad Volponiho postavy (robotník Albino Saluggia v Memoriali alebo rol'ník Anteo Crociani v La macchina mondiale), v slovenskom výrobnom románe či v občiansko-politickej literatúre je dielo vystavané na hrdinstve obyčajného človeka. Výnimku tvorí tvorba Prima Leviho (chýbajúci kritický šlah, autor vyjadruje skôr pozitívny pohlad na svet práce), ako sme však uviedli, jeho zaradenie do kontextu industriálnej literatúry je diskutabilné. Základnú diferenciu môžeme badat aj zo žánrového hladiska: tendencia románovej tvorby (industriálny román) v Taliansku, v Československu skôr požiadavka kratších prozaických útvarov a satiry.

Ako funkčne pripomína nitriansky talianista Fabio Gritti, „predmetom pozornosti tu už nie je rurálny svet, ale prostredie fabrik, dielni, ako aj úradov, ale podobný neorealizmu ostáva spôsob, ako sa stavat’ voči realite“, pričom cituje Ferrettiho názor, že industriálna literatúra (najmä v rokoch 1957-1958) je akousi poslednou "reinkarnáciou neorealizmu“ ${ }^{25}$

Pre československý socialistický režim bol tento typ literatúry ideologicky vhodný len pre jeho kritický tón smerom k negatívnym konzekvenciám kapitalizmu. Kritika kapitalizmu bola však len jednou častou (z literárnovedného hladiska témou) talianskej in-

24 V tejto súvislosti by sme chceli poukázat na štúdiu talianistky Daniely Laudaniovej v konferenčnom zborníku prác Preklad a tlmočenie 4, v ktorej analyzuje viaceré osobnosti talianskej literatúry z hladiska ich prekladovej produkcie. Všíma si aj viaceré Vittoriniho zásluhy (preklady Steinbecka, Caldwella, Gaina, prípravu excelentnej antológie Americana). Pripomína však, že tamojšie Ministerstvo ludovej kultúry jeho knihy a preklady často cenzurovalo alebo priamo zakázalo vydat', najmä preto, lebo nebol dostatočne heroický. Na druhej strane je potrebné pripomenút aj fakt, že viacerí autori, ako práve spomínaný Vittorini, ale aj Pavese, Montale a iní sledovali svojimi prekladmi antifašistický odkaz. Viac k téme porov. LAUDANI, Daniela: Talianska translatológia - vývoj prekladatelského myslenia v Taliansku s dôrazom na románske jazyky. In: Preklad a tlmočenie 4. Banská Bystrica: Filologická fakulta UMB, Katedra slovakistiky, 2002, s. 60-87. 
dustrializovanej literatúry. Kritický postoj k industrializácii spoločnosti (či presnejšie ich konzekvencií), ktorá sa uskutočňovala od pätdesiatych rokov 20. storočia, však negatívne vplýval aj na (česko)slovenského recipienta. Tematické a výrazové zobrazovanie reality $\mathrm{v}$ čase československého socialistického realizmu bolo v rozpore s ideami talianskych lavicových intelektuálov, ktorí odmietali ždanovovskú politiku zasahovania ideológie do literatúry a jej direktívne riadenie prostredníctvom štátnej politiky.

Za problematické sa $\mathrm{v}$ našom kontexte javilo aj celkové zaradenie a charakteristika tohto typu literatúry. Už Elio Vittorini zhodnotil v štvrtom čísle časopisu Menabò v roku 1961 industriálny román ako formálne a obsahovo inovačný. Takto sa ujal aj v tamojšej literárnej kritike, a to stažovalo jeho interpretáciu v kontúrach socialistického realizmu u nás. ${ }^{26} \mathrm{Aj}$ preto bol priemyselný román „u nás prezentovaný ako literatúra kritiky chýbajúcej humanity a morálky $v$ západnom svete ${ }^{\text {“ }}{ }^{27}$ Taliansky priemyselný román teda musíme vnímat $\mathrm{v}$ širšom slovenskom recepčnom kontexte -, a to v (ne)zhode s vtedajším literárnym, resp. kultúrno-literárnym vývinom u nás.

Na záver dodajme, že opačný smer (t. j. preklad autorov slovenskej industrializovanej literatúry do taliančiny) sme nezaznamenali. Okrem ideologických dôvodov je za tým aj výrazná orientácia na slovenské hospodársko-sociálne pomery (t. j. geograficky uzatvorený priestor s reáliami, ktoré sú naviazané na slovenský kontext a primárne určené pre potenciálneho slovenského čitatela) a v širšom kontexte ide o nezáujem zahraničných vydavatel'stiev o tzv. malé literatúry (d’urišinovsky povedané málo diferencované literatúry, resp. politicky korektný výraz literatúry z málo/menej rozšírených jazykov).

\section{Literatúra}

BALDI, Guido - GIUSSO, Silvia: La letteratura. Dal dopoguerra ai giorni nostri. Pioltello (Milano): Paravia, 2007.

BÍLIK, René: Duch na retazi. Sondy do literárneho života na Slovensku v rokoch 1945-1989. Bratislava: Kalligram, 2008.

DE NICOLA, Francesco: Gli scrittori italiani e l'emigrazione. Roma: Ghenomena, 2008.

DE NICOLA, Francesco: Letteratura italiana contemporanea. Dall' Unità nazionale all'era televisiva. Genova: De Ferrari, 2006.

FERRONI, Giulio: Storia della letteratura italiana. Il Novecento e il nuovo millenio. Milano: Mondadori, 2013.

GRITTI, Fabbiano: Il dibattito critico sul neorealismo. In: Studi italo-slovacchi 2 (11), 2012, č. 1, s. 7-38.

JENČÍKOVÁ, Eva a kol.: Čítame slovenskú literatúru II. Bratislava: Ústav slovenskej literatúry SAV, 1997.

KOPRDA, Pavol: Talianska literatúra v slovenskej kultúre v rokoch 1890-1980. (Stručné dejiny umelec-

26 KOPRDA, Pavol: Talianska literatúra v slovenskej kultúre v rokoch 1890-1980. (Stručné dejiny umeleckého prekladu na Slovensku. Zv. 1. Talianska literatúra). Bratislava: Ústav svetovej literatúry SAV, 1994, s. 64.

27 SABOLOVÁ, Dagmar: Recepcia talianskej literatúry na Slovensku v 80. a 90. rokoch 20. storočia. In: ToP (Tlumočení a překlad) 7, 1996, č. 30, s. 14 . 
kého prekladu na Slovensku. Zv. 1. Talianska literatúra). Bratislava: Ústav svetovej literatúry SAV, 1994.

KOPRDA, Pavol: Talianska literatúra (zväzok 8a.) Dvadsiate storočie do fašizmu. Nitra: FF UKF, 2014.

LAJČIAK, Milan: Somknút sily na pomoc súbornému plánu. In: Kultúrny život, č. 10, s. 4, 1952.

LAUDANI, Daniela: Talianska translatológia - vývoj prekladatelského myslenia v Taliansku s dôrazom na románske jazyky. In: Preklad a tlmočenie 4. Banská Bystrica: Filologická fakulta UMB, Katedra slovakistiky, 2002, s. 60-87.

MARČOK, Viliam a kolektív: Dejiny slovenskej literatúry III. (Druhé, rozšírené vydanie). Bratislava: Literárne informačné centrum, 2006.

OTTIERI, Ottiero: Dennik psychológa. Prel. Marína Miháliková-Hečková. Bratislava: Tatran, 1980.

POSPÍŠIL, Ivo: Literárni genologie. Brno: Masarykova univerzita, 2014.

POSPÍŠIL, Ivo: Literárni věda a teritorialni studie. Nitra: FSŠ UKF, 2013.

SABBATUCCI, Giovanni - VIDOTTO, Vittorio: Storia contemporanea. Il Novecento. Roma-Bari: Editori Laterza, 2007.

SABOLOVÁ, Dagmar: Recepcia talianskej literatúry na Slovensku v 80. a 90. rokoch 20. storočia. In: ToP (Tlumočení a překlad) 7, 1996, č. 30, s. 13-15.

SEGRE, Cesare. et al.: La letteratura italiana del Novecento. Roma-Bari: Laterza, 1998.

SEGRE, Cesare - MARTIGNONI, Clelia: Testi nella storia. La letteratura italiana dalle origini al Novecento. Il Novecento. Volume 4. Pioltello (Milano): Mondadori, 1992.

SEIDL, Ivan: La letteratura italiana del Novecento. Brno: Univerzita Jana Evangelisty Purkyně, Filozofická fakulta, 1985.

ŠUŠA, Ivan: Holokaust v talianskej a slovenskej memoárovej literatúre. Brno: Tribun EU a FF MU, 2009.

ŠUŠA, Ivan: Komparatistické a prekladové aspekty v slovensko-talianskych medziliterárnych vztahoch. Banská Bystrica: FHV UMB, 2011.

ŠUŠA, Ivan: Talianska literatúra v slovenskom prekladovo-recepčnom kontexte po roku 1989. Banská Bystrica: FF UMB, 2017.

doc. PhDr. Ivan Šuša, Ph.D.

Katedra translatológie

Filozofická fakulta, Univerzita Mateja Bela

Tajovského 40, 97400 Banská Bystrica, Slovensko

ivan.susa@umb.sk
Dr. Patrizia Prando, PhD.

Katedra politológie

Fakulta politických vied a medzinárodných vztáahov,

Univerzita Mateja Bela

Kuzmányho 1, 97401 Banská Bystrica, Slovensko

patrizia.prando@umb.sk 